Prepared for the U.S. Department of Energy

Under Contract DE-AC05-76RL01830

\title{
Status Report for Remediation Decision Support Project, Task 1, Activity 1.B - Physical and Hydraulic Properties Database and Interpretation
}

ML Rockhold

September 2008

\section{Pacific Northwest}

NATIONAL LABORATORY

Proudly Operated by Battelle Since 1965 


\title{
DISCLAIMER
}

This report was prepared as an account of work sponsored by an agency of the United States Government. Neither the United States Government nor any agency thereof, nor Battelle Memorial Institute, nor any of their employees, makes any warranty, express or implied, or assumes any legal liability or responsibility for the accuracy, completeness, or usefulness of any information, apparatus, product, or process disclosed, or represents that its use would not infringe privately owned rights. Reference herein to any specific commercial product, process, or service by trade name, trademark, manufacturer, or otherwise does not necessarily constitute or imply its endorsement, recommendation, or favoring by the United States Government or any agency thereof, or Battelle Memorial Institute. The views and opinions of authors expressed herein do not necessarily state or reflect those of the United States Government or any agency thereof.

\author{
PACIFIC NORTHWEST NATIONAL LABORATORY \\ operated by \\ BATTELLE \\ for the \\ UNITED STATES DEPARTMENT OF ENERGY \\ under Contract DE-AC05-76RL01830
}

Printed in the United States of America

\author{
Available to DOE and DOE contractors from the Office of Scientific and Technical \\ Information, \\ P.O. Box 62, Oak Ridge, TN 37831-0062; ph: (865) 576-8401 fax: (865) 576-5728 email: \\ reports@adonis.osti.gov
}

\begin{abstract}
Available to the public from the National Technical Information Service, U.S. Department of Commerce, 5285 Port Royal Rd., Springfield, VA 22161 ph: (800) 553-6847 fax: (703) 605-6900

email: orders@ntis.fedworld.gov online ordering: http://www.ntis.gov/ordering.htm
\end{abstract}




\section{Status Report for Remediation Decision Support Project, Task 1, Activity 1.B - Physical and Hydraulic Properties Database and Interpretation}

ML Rockhold

September 2008

Prepared for

the U.S. Department of Energy

under Contract DE-AC05-76RL01830

Pacific Northwest National Laboratory

Richland, Washington 99352 



\section{Executive Summary}

The objective of Activity 1.B of the Remediation Decision Support (RDS) Project is to compile all available physical and hydraulic property data for sediments from the Hanford Site, to port these data into the Hanford Environmental Information System (HEIS), and to make the data web-accessible to anyone on the Hanford Local Area Network via the so-called Virtual Library.

In past years efforts were made by RDS project staff to compile all available physical and hydraulic property data for Hanford sediments and to transfer these data into SoilVision ${ }^{\circledR}$, a commercial geotechnical software package designed for storing, analyzing, and manipulating soils data. Although SoilVision ${ }^{\circledR}$ has proven to be useful, its access and use restrictions have been recognized as a limitation to the effective use of the physical and hydraulic property databases by the broader group of potential users involved in Hanford waste site issues. In order to make these data more widely available and useable, a decision was made to port them to HEIS and to make them web-accessible via a Virtual Library module.

In FY08 the original objectives of Activity 1.B of the RDS Project were to: (1) ensure traceability and defensibility of all physical and hydraulic property data currently residing in the SoilVision ${ }^{\circledR}$ database maintained by the Pacific Northwest National Laboratory (PNNL), (2) transfer the physical and hydraulic property data from the Microsoft Access database files used by SoilVision ${ }^{\circledR}$ into HEIS, which has most recently been maintained by Fluor-Hanford, Inc., (3) develop a Virtual Library module for accessing these data from HEIS, and (4) write a User's Manual for the Virtual Library module. The development of the Virtual Library module was to be performed by a third party under subcontract to Fluor. The intent of these activities is to make the available physical and hydraulic property data more readily accessible and useable by technical staff and operable unit managers involved in waste site assessments and remedial action decisions for Hanford.

In FY08 communications were established between PNNL and Fluor-Hanford, Inc. staff to outline the design of the Virtual Library module that would be used to access physical and hydraulic property data that were transferred from SoilVision ${ }^{\circledR}$ into HEIS. Data dictionaries used by SoilVision ${ }^{\circledR}$ were also provided to Fluor staff. During ongoing work to ensure traceability and defensibility of all physical and hydraulic property data that currently reside in the SoilVision ${ }^{\circledR}$ database, it was recognized that further work would be required in this effort before the data were actually ported to HEIS. Therefore work on the Virtual Library module development and an accompanying User's Guide was deferred. This status report describes the history of this development effort and the progress to date. 



\section{Acknowledgments}

The Hanford Vadose Zone Physical and Hydraulic Properties Database development was initiated by Gene Freeman (formerly with PNNL) and George Last (PNNL), who compiled historical data sets generated by various site contractors into a series of Excel spreadsheets. This work was continued by Andy Ward (PNNL) and Jason Keller (formerly with PNNL) who were responsible for generating some of the more recent data, and for porting historic data as well as the more recent data into SoilVision ${ }^{\circledR}$. Data entry into SoilVision ${ }^{\circledR}$ has been performed by various PNNL staff and summer students. The contributions of all of these people are acknowledged. 



\section{Acronyms and Abbreviations}

HEIS

Hanford Environmental Information System 



\section{Contents}

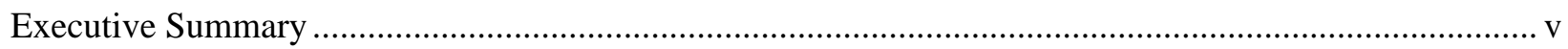

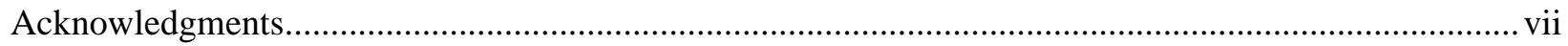

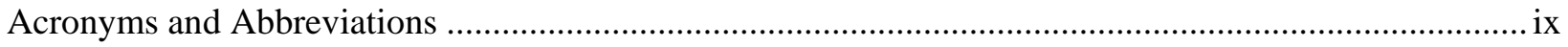

1.1 Screen shot of SoilVision ${ }^{\circledR}$ website advertising capabilities.......Error! Bookmark not defined.

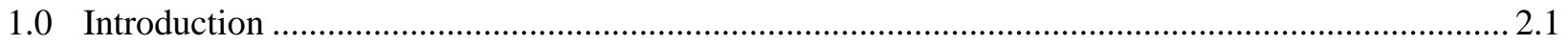

2.0 Physical and Hydraulic Properties Database ................................................................................... 2.1

3.0 Virtual Library Module Development Plan ........................................................................... 3.1

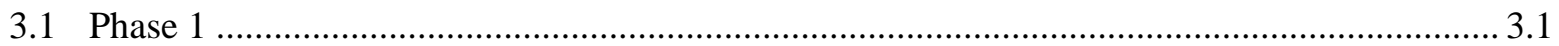

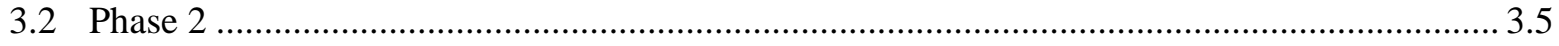

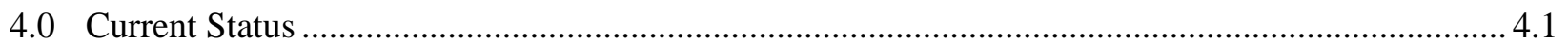

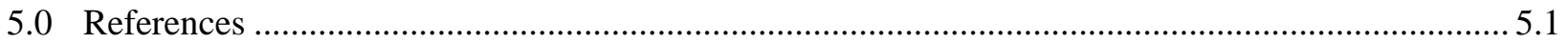




\section{Figures}

Figure 2.1 Screenshot of SoilVision Website Advertising Capabilities ................................................. 2.1

Figure 2.2. Hanford Site-Specific Soilvision ${ }^{\circledR}$ Databases .................................................................... 2.2 


\section{Tables}

Table 3.1. Borehole Information Data Fields ............................................................................... 3.1

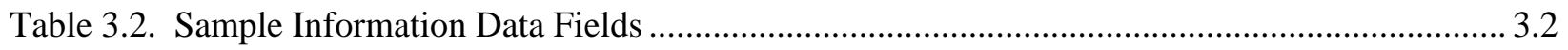

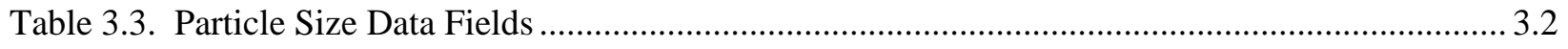

Table 3.4. Field Moisture Content Data Fields ................................................................................ 3.2

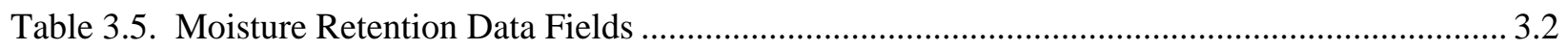

Table 3.6. Saturated Hydraulic Conductivity Data Fields ........................................................................ 3.3

Table 3.7. Unsaturated Hydraulic Conductivity Data Fields ............................................................... 3.3

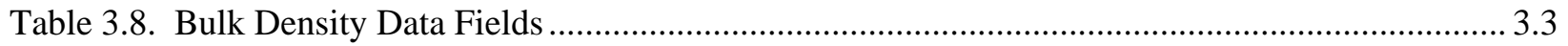

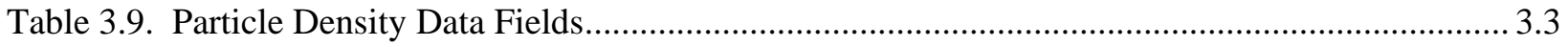

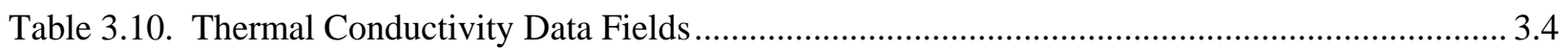





\subsection{Introduction}

Over the more than 60 years of Hanford Site operations significant efforts have been made to measure the physical properties of sediments underlying the Hanford Site, such as grain size distributions, bulk and particle densities, and porosities. During the past 30 years or so that effort has grown to include the measurement of hydraulic properties, which include saturated hydraulic conductivities, relative permeabilities for different fluid phases, and pressure-saturation data. Much of this effort is driven by the need to accurately estimate contaminant transport in the subsurface for the purpose of remedial investigations and site assessments.

Physical and hydraulic properties are fundamental data for any type of quantitative analysis of contaminant transport and fate in the subsurface, including evaluation of risk associated with natural attenuation (no-action) or engineered remedial action alternatives at waste sites (e.g. biostimulation or InSitu Redox Manipulation [ISRM] for chromium reduction, emplacement of surface infiltration barriers and soil dessication to minimize transport of technetium and other radionuclides, soil-vapor extraction for carbon tetrachloride removal, etc.). Therefore the Physical and Hydraulic Property Database and Interpretation activity of the RDS Project directly supports DOE’s mission at the Hanford Site.

The efforts made to generate physical and hydraulic property data for Hanford sediments have resulted in the compilation of numerous data sets acquired by different contractors and individuals using different measurement methods, with data processing by different software, and with files stored in different locations. In order to more efficiently use the existing data, and to help reduce duplication of efforts, a process was initiated to compile into a single location the various Hanford sediment physical and hydraulic property datasets. A part of this effort is the transformation of the datasets into a form that allows the data to be presented and used in a consistent manner.

The purpose of this report is to document the status of work being conducted under Task 1, Activity 1.B of the Remediation Decision Support (RDS) Project. The objectives of this activity are to compile all available physical and hydraulic property data for sediments from the Hanford Site, to port these data into the Hanford Environmental Information System (HEIS), and to make the data web-accessible to anyone on the Hanford Local Area Network via the so-called Virtual Library ${ }^{1}$.

\footnotetext{
${ }^{1}$ A Web-based graphical user interface that allows querying of HEIS databases, plotting, and data export.
} 



\subsection{Physical and Hydraulic Properties Database}

The Physical and Hydraulic Properties Database began as a collection of data compiled into Microsoft Excel worksheets as documented by Freeman and Last (2003). This informal database brought together to a single location various Hanford data sets, but the database was not all inclusive, and lacked querying, visualization, and export capabilities. Under the Characterization of Systems (now the RDS) project the data in the Freeman and Last (2003) database was imported into a software program called SoilVision ${ }^{\circledR}$.

SoilVision ${ }^{\circledR}$ (http://www.soilvision.com) is a commercial geotechnical software package designed for storing and analyzing soils data. Several versions of the software are available. The full version (Figure 2.1) is essentially a database system, based on Microsoft Access, with capabilities for estimating soil properties such as grain-size distribution metrics, soil or sediment classifications, and hydraulic parameters from basic soils data. Analytical capabilities also include statistical analyses and the ability to fit different analytic functions to the data, including so-called pedo-transfer function models, to generate parameters that can be used for water flow and solute transport modeling. The Professional version also allows access to a database of properties for over 6000 soils that have been collected worldwide.

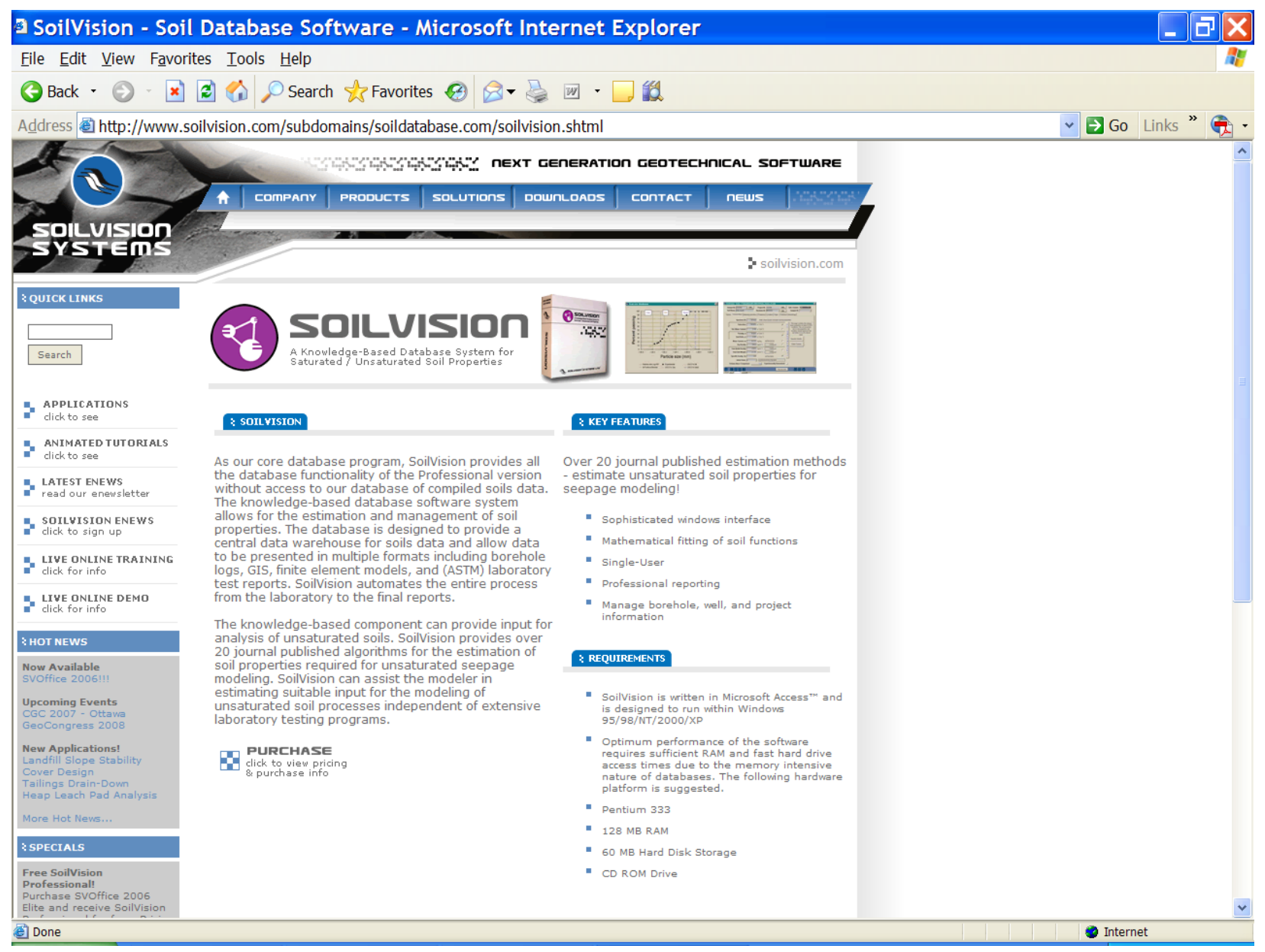

Figure 2.1 Screenshot of SoilVision Website Advertising Capabilities 
The SoilVision ${ }^{\circledR}$ database structure allows for many different types of geotechnical data to be stored, including physical properties (e.g. grain-size distribution data, bulk and particle density, porosity, etc.) and hydraulic properties (e.g. saturated hydraulic conductivity, water retention characteristics, relative permeability, etc.), which are of the greatest interest to the Hanford community. The SoilVision ${ }^{\circledR}$ database for Hanford sediments was expanded from the Freeman and Last (2003) database to include other physical and hydraulic property datasets that were identified as being reliable. These included datasets generated by various Hanford Site contractors including Rockwell Hanford, Operations (RHO), Westinghouse Hanford Company (WHC), Fluor Hanford, Inc. (FH), the Pacific Northwest National Laboratory (PNNL), and others.

Figure 2.2 lists some of the sites that are currently represented in the SoilVision ${ }^{\circledR}$ database maintained by PNNL. The sites represented in the database include the 300 Area (Schalla_1997_D.mdb), BC Cribs and Trenches (SVSoils_BCCrib_D.mdb), the ILAW site (SVSoils_ILAW_D.mdb), the Sisson \& Lu Site (SVSoils_S\&L_D.mdb), a clastic dike study site (SVSoils_VZTFFY03_D.mdb), and a compilation of data collected at various locations around the site by the WHC Geotechnical Engineering Lab (GEL) which no longer exists (SVSoils_Freeman_D.mdb). Note that the data in Schalla_1997_D.mdb represent data reported by Schalla et al. (1988), collected more than 20 years ago, and which was previously available only in hardcopy records. These and other historical data had to be entered by hand from the hardcopy records into Excel spreadsheets or directly into SoilVision ${ }^{\circledR}$. The datasets also include grain-size distribution data for over 30,000 sediment samples collected during well drilling at Hanford from the historical ROCSAN database (SV_Rocsan_1997_D.mdb), which are already accessible via the Virtual Library. The database (*.mdb) files shown in Figure 2 are currently static, but other similar database files are being actively developed on other projects for other sites at Hanford. These files are not under any formal configuration management at this time. Hence these database files should be considered informal.

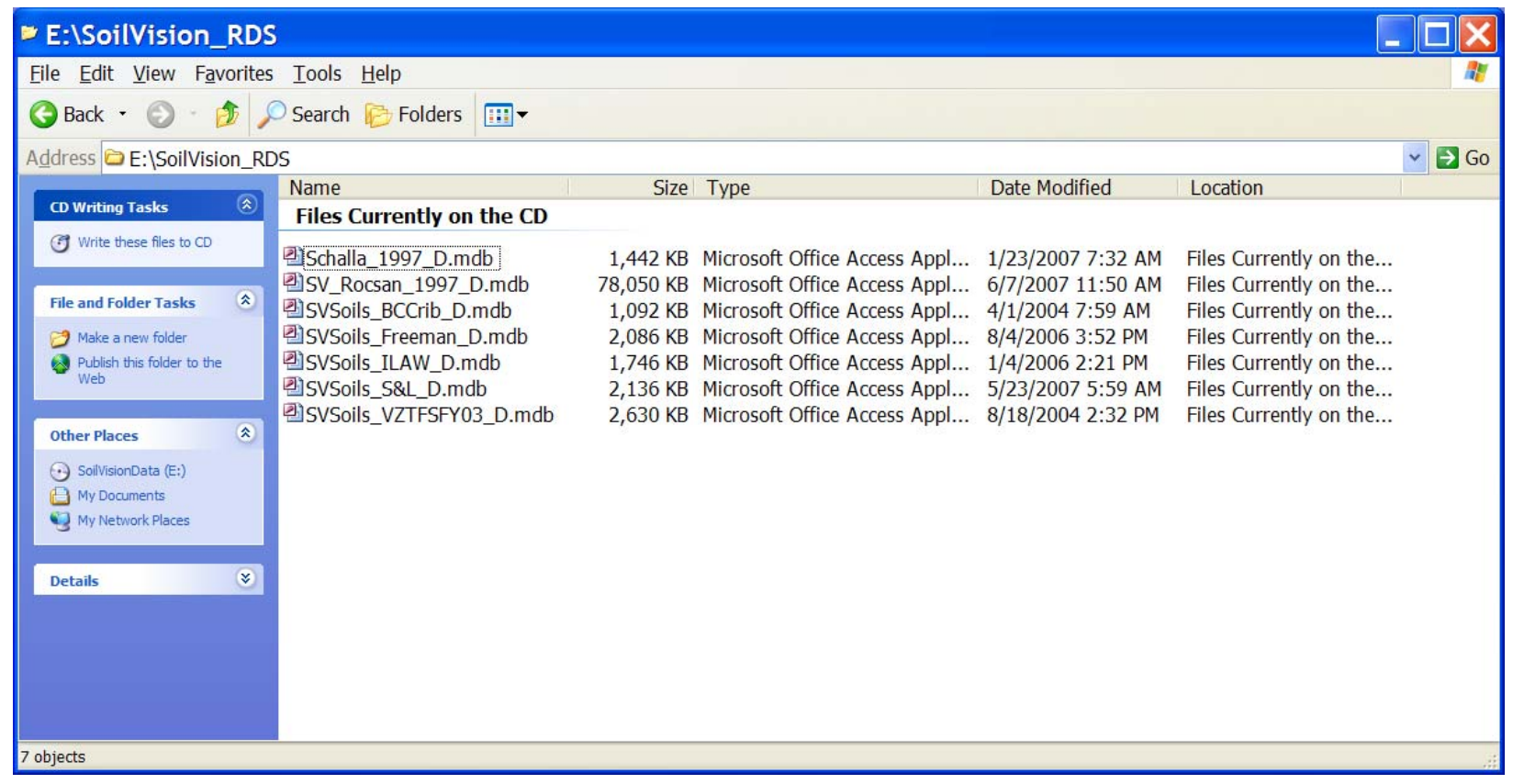

Figure 2.2. Hanford Site-Specific Soilvision ${ }^{\circledR}$ Databases 
When these data or selected subsets of them are transferred into HEIS, and made accessible via the Hanford Virtual Library, they will become official and will be placed under formal configuration management and control. Additional data on physical and hydraulic properties for Hanford sediments are expected to be developed over time for different projects in support of various research activities and sitespecific remedial investigations.

SoilVision ${ }^{\circledR}$ operates exclusively on PCs and requires a license that is activated by the use of a “dongle" (a USB thumb drive) that must reside on the computer on which SoilVision ${ }^{\circledR}$ is installed and being used. PNNL owns several single-license versions of SoilVision ${ }^{\circledR}$. Although SoilVision ${ }^{\circledR}$ has proven to be useful, its access and use restrictions have been recognized as a limitation to the effective use of the physical and hydraulic property databases by the broader group of potential users involved in Hanford waste site issues. In order to make these data more widely available and useable, the decision was made to port the databases to HEIS and to make them web-accessible via a Virtual Library module. 



\subsection{Virtual Library Module Development Plan}

Under the RDS project, PNNL initiated a Physical and Hydraulic Properties Database and Interpretation activity, and the associated development of a web-based graphical user interface, or Visual Library module, in partnership with Fluor-Hanford, Inc. The primary objective of this work is for all Hanford Local Area Network (HLAN) users to have web-based access to the physical and hydraulic properties contained in the database, with capabilities for visualization, querying, and exporting of data. The following plan was developed following discussions between Mark Rockhold (PNNL), George Last (PNNL), and Bill Webber (formerly Fluor-Hanford, Inc.) on Oct. 24, 2007.

The Physical and Hydraulic Property Database and Interpretation activity was planned in two phases. Phase 1, initiated in FY08, involves (1) establishing the traceability and defensibility of all physical and hydraulic property data currently maintained by PNNL that are to be transferred into HEIS, (2) transferring the "raw" data from the Microsoft Access database files used by SoilVision ${ }^{\circledR}$ to HEIS, (3) development of a Virtual Library module for accessing, visualizing, and exporting the data from HEIS, and (4) writing a User's Manual for the Virtual Library module. Phase 2 is expected to involve the development of on-line and downloadable tools for data analysis and interpretation to enhance the usefulness of the raw data.

\subsection{Phase 1}

During FY08, communications were established between Fluor (Bill Webber) and PNNL staff (Mark Rockhold and George Last) to coordinate the development of the Virtual Library module, which was to be programmed by a third party under subcontract to Fluor. Data dictionaries from SoilVision ${ }^{\circledR}$ were transferred from PNNL to Fluor, and general design specifications for Phase 1 of the Virtual Library module development were articulated. The primary data for the Hanford Physical and Hydraulic Properties Database are to include (but are not limited to) the following types, shown in Tables 3.1 - 3.10.

Table 3.1. Borehole Information Data Fields

\begin{tabular}{|l|l||}
\hline \multicolumn{1}{|c||}{ Data Field } & \multicolumn{1}{c||}{ Description } \\
\hline Borehole_ID & ID of borehole. \\
\hline Drilling_Method & Method used to drill borehole. \\
\hline Logged_by & Person responsible for logging borehole. \\
\hline Borehole_Notes & Notes regarding borehole. \\
\hline Total_Depth & Total depth of borehole (m). \\
\hline Surface_Elevation & Surface elevation at the top of the borehole (m). \\
\hline Ground_Height & Height of the top of the borehole above the ground surface (m). \\
\hline Latitude & Latitude of borehole location. \\
\hline Longitude & Longitude of borehole location. \\
\hline Easting & Washington State Plane coordinates. \\
\hline Northing & Washington State Plane coordinates. \\
\hline Operable Unit Designation & \\
\hline
\end{tabular}


Table 3.2. Sample Information Data Fields

\begin{tabular}{|l|l||}
\hline \multicolumn{1}{|c|}{ Data Field } & \multicolumn{1}{c||}{ Description } \\
\hline Borehole_ID & ID of Borehole from which soil sample was collected. \\
\hline Sample_ID & A character string used to uniquely identify the soil sample. \\
\hline Geologic_Description & Geologic description and soil or stratigraphic unit class of the current soil. \\
\hline Notes & Notes about the current soil. \\
\hline Contact & Individual that contributed soil data to database. \\
\hline Date_Sampled & Date soil was sampled. \\
\hline Land_Use & Land use where soil sample was obtained. \\
\hline Sample_Depth_Upper & Depth to location of top of soil sample (m). \\
\hline Sample_Depth_Lower & Depth to location of bottom of soil sample (m). \\
\hline Author & Author of publication if published. \\
\hline Reference & Full citation for publication or laboratory record book and number. \\
\hline \hline
\end{tabular}

Table 3.3. Particle Size Data Fields

\begin{tabular}{|l|l||}
\hline \multicolumn{1}{|c||}{ Data Field } & \multicolumn{1}{c||}{ Description } \\
\hline Grainsize_Test_Method & Test method used to obtain experiment results. \\
\hline Grainsize_Technician & Technician responsible for experiment results. \\
\hline Grainsize_Lab_Notes & Notes by laboratory technician. \\
\hline graeParticle_Diameter & Sieve analysis, particle diameter (mm). \\
\hline graePercent_Passing & Sieve analysis, percent passing the particle diameter sieve. \\
\hline grahParticle_Diameter & Hydrometer analysis, particle diameter (mm). \\
\hline grahPercent_Passing & Hydrometer analysis, percent passing the particle diameter sieve. \\
\hline
\end{tabular}

Table 3.4. Field Moisture Content Data Fields

\begin{tabular}{|l|l|}
\hline \multicolumn{1}{|c|}{ Data Field } & \multicolumn{1}{c|}{ Description } \\
\hline WC_Test_Method & Test method used to obtain experiment results. \\
\hline WC_Technician & Technician responsible for experiment results. \\
\hline WC_Lab_Notes & Notes by laboratory technician. \\
\hline Water_Content & Gravimetric moisture content of sample. \\
\hline \hline
\end{tabular}

Table 3.5. Moisture Retention Data Fields

\begin{tabular}{||l|l||}
\hline \multicolumn{1}{|c||}{ Data Field } & \multicolumn{1}{c||}{ Description } \\
\hline SWCC_Test_Method & Test method used to obtain drying curve experimental results. \\
\hline SWCC_Technician & Technician responsible for drying curve experimental results. \\
\hline SWCC_Lab_Notes & Drying curve notes by laboratory technician. \\
\hline voledSuction & Drying curve, suction of soil (kPa). \\
\hline voledWater_Content & Drying curve, gravimetric water content of soil. \\
\hline SWCCW_Test_Method & Test method used to obtain wetting curve experimental results. \\
\hline
\end{tabular}




\begin{tabular}{|l|l|}
\hline \multicolumn{1}{|c|}{ Data Field } & \multicolumn{1}{c|}{ Description } \\
\hline SWCCW_Technician & Technician responsible for wetting curve experiment results. \\
\hline SWCCW_Lab_Notes & Wetting curve notes by laboratory technician. \\
\hline volewSuction & Wetting curve, suction of soil (kPa). \\
\hline volewWater_Content & Wetting curve, gravimetric water content of soil. \\
\hline \hline
\end{tabular}

Table 3.6. Saturated Hydraulic Conductivity Data Fields

\begin{tabular}{|l|l||}
\hline \multicolumn{1}{|c|}{ Data Field } & \multicolumn{1}{c|}{ Description } \\
\hline ksat_Test_Method & Test method used to obtain experiment results. \\
\hline ksat_Technician & Technician responsible for experiment results. \\
\hline ksat_Lab_Notes & Notes by laboratory technician. \\
\hline Laboratory_ksat & Saturated hydraulic conductivity measured in the laboratory (m/s). \\
\hline Field_ksat & Saturated hydraulic conductivity measured in the field (m/s). \\
\hline
\end{tabular}

Table 3.7. Unsaturated Hydraulic Conductivity Data Fields

\begin{tabular}{|l|l||}
\hline \multicolumn{1}{|c||}{ Data Field } & \multicolumn{1}{c|}{ Description } \\
\hline Permeability_Test_Method & Test method used to obtain experiment results. \\
\hline Permeability_Technician & Technician responsible for experiment results. \\
\hline Permeability_Lab_Notes & Notes by laboratory technician. \\
\hline hydefSuction & Field measured, current soil suction $(\mathrm{kPa})$. \\
\hline hydefConductivity & Field measured, current soil hydraulic conductivity $(\mathrm{m} / \mathrm{s})$. \\
\hline hydeSuction & Lab measured, current soil suction $(\mathrm{kPa})$. \\
\hline hydeConductivity & Lab measured, current soil hydraulic conductivity $(\mathrm{m} / \mathrm{s})$. \\
\hline
\end{tabular}

Table 3.8. Bulk Density Data Fields

\begin{tabular}{|l|l||}
\hline \multicolumn{1}{|c||}{ Data Field } & \multicolumn{1}{c|}{ Description } \\
\hline Dry_Density & Dry bulk density $\left(\mathrm{kg} / \mathrm{m}^{3}\right)$. \\
\hline Total_Density & Total (wet) bulk density $\left(\mathrm{kg} / \mathrm{m}^{3}\right)$. \\
\hline
\end{tabular}

Table 3.9. Particle Density Data Fields

\begin{tabular}{||l|l||}
\hline \multicolumn{1}{|c||}{ Data Field } & \multicolumn{1}{c|}{ Description } \\
\hline SG_Test_Method & Test method used to obtain experiment results \\
\hline SG_Technician & Technician responsible for experimental results \\
\hline SG_Lab_Notes & Notes by laboratory technician \\
\hline Particle Density & Particle density $\left(\mathrm{kg} / \mathrm{m}^{3}\right)$ \\
\hline \hline
\end{tabular}


Table 3.10. Thermal Conductivity Data Fields

\begin{tabular}{|l|l||}
\hline \multicolumn{1}{|c||}{ Data Field } & \multicolumn{1}{c|}{ Description } \\
\hline Thermal_Test_Method & Test method used to obtain experiment results \\
\hline Thermal_Technician & Technician responsible for experimental results \\
\hline Thermal_Lab_Notes & Notes by laboratory technician \\
\hline theeSuction & Suction of soil $(\mathrm{kPa})$ \\
\hline theeThermal_Conductivity & Thermal conductivity of soil (W/m.C) \\
\hline
\end{tabular}

After physical and hydraulic property datasets have been transferred from SoilVision ${ }^{\circledR}$ to HEIS, a user should be able to access these data through a Web-based Virtual Library module. For Phase 1, this module will be designed to include the following capabilities:

- data import

- querying

- visualization

- data export.

Access to data import capabilities will be limited to key staff at PNNL and Fluor or another contractor responsible for continued HEIS development and maintenance. Capabilities for querying the database will be needed to allow a user to specify the area or wells of interest, the data type(s) of interest, including query by soil classification and stratigraphic unit, and to select whether to visualize or export the data, or both. Since Phase 1 of this work will focus on the "raw" data, visualization in Phase 1 will be limited to simple $\mathrm{x}-\mathrm{y}$ plots showing, for example, grain size versus percent passing, or soil moisture content versus tension, etc. If multiple wells, or an area (e.g. 200 West), or an operable unit (e.g. 200$\mathrm{PW}-1$ ) is selected, it will also be useful to be able to visualize the $\mathrm{x}-\mathrm{y}$ locations of all borehole locations that have data of the type(s) selected in the query. For data export a user should be able to output the requested data in ASCII text, CSV, or other standard formats. In addition, a user should be able to request that the data be exported in user-specified units such that unit conversions are automatically performed (e.g. $\mathrm{cm} / \mathrm{s}$ to $\mathrm{m} / \mathrm{d}$ ) on the exported data.

Although transfer of some of the raw physical and hydraulic data from PNNL to Fluor was initiated in FY08, inspection of some of the data fields in the existing SoilVision ${ }^{\circledR}$ database files indicated that additional effort would be required to firmly establish the traceability and defensibility of some of these data sets. One area that requires particular attention is the incorporation of so-called metadata. The full citations for publications or other references to laboratory record books and their numbers were lacking or incomplete for some of the datasets. This metadata is critical for establishing the traceability and defensibility of data. Therefore work to establish the traceability and defensibility of some of the data sets is ongoing. As a consequence, development of the Virtual Library module and User's Manual for Phase 1 was delayed. Data transfer and development of the Virtual Library module and associated User's Manual will resume in FY09, contingent upon approval by the new contractor responsible for ongoing RDS Project work scope. 


\subsection{Phase 2}

In Phase 2 of this effort, additional data fields (e.g. thermal properties) and data analysis capabilities were planned for the Virtual Library module. The added data fields will include, for example, parameters that describe the water retention characteristics and unsaturated hydraulic conductivities of the soil or sediment based on fitting the raw data with user-defined analytic functions. Currently, this sort of fitting is routinely performed using simple spreadsheet programs such as Excel ${ }^{\circledR}$. For Phase 2 our intent is to provide on-the-fly fitting capabilities through the Virtual Library module, but also to make such spreadsheet-based fitting and parameter estimation tools available for easy download and use outside of the Virtual Library module. A user should also be able to request parameter estimates based on so-called pedotransfer functions, which are regression-based correlation functions that relate variables such as grain-size distribution metrics to hydraulic or sorption parameters. Numerous pedotransfer functions have been reported in the literature (Guber et al. 2006; Ward et al. 2006), and Hanford site-specific pedotransfer functions are under development by PNNL.

Additional data fields to be added in Phase 2 would include various grain-size distribution metrics and sediment classifications based on such. Examples of some uses of these types of data are provided by Oostrom et al. (2006), and Williams et al. (2008).

The visualization capabilities developed in Phase 1 would logically be expanded in Phase 2 such that any fitted model(s) could be superimposed on the "raw" data, along with statistical measures of goodnessof-fit, so that a user can evaluate the quality of the fitted parameters. At this point, we think the ability to view the available data in 3D is probably unnecessary, although this is subject to debate. Further discussion may also be required on possible data input options to be developed during Phase 2 . Restrictions on data input will obviously be needed to ensure that only high-quality and traceable data are entered into the database. This will likely require that administrative privileges be granted to only a few authorized individuals at both PNNL and the contractor responsible for continuing the development and maintenance of the HEIS database. Although anyone on the HLAN should have access to the physical and hydraulic property data that will be contained in HEIS and that will be accessible via the Virtual Library, incorporation of new data should require independent QA/QC review and import into the Virtual Library by qualified staff who are designated points-of-contact (POC) or their delegates. The current POCs for the Physical and Hydraulic Property Database and HEIS/Virtual Library module development are Mark Rockhold (PNNL) and Bill Webber (Fluor-Hanford), respectively. No new data export features are currently envisioned for Phase 2, aside from the additional data types that will be available for export. The User's Manual for the Virtual Library module will also be updated at the end of Phase 2 to describe and document the new analysis capabilities. 



\subsection{Current Status}

Originally, the primary deliverable for Activity 1.B in FY08 was a User's Manual for the Virtual Library module. Completion of this deliverable was contingent upon first verifying traceability and defensibility of all data to be transferred to HEIS, then transferring the verified data into HEIS, and then developing the Virtual Library module, with the latter being outside of the direct control of PNNL. Owing to difficulties in establishing traceability and defensibility of some of the data now residing in the SoilVision ${ }^{\circledR}$ database (which currently represents data collected by different individuals and contractors over the past 20+ years) and to the postponement of Virtual Library module development activities, this deliverable was deferred. Efforts are ongoing to establish the treaceability and defensibility of all physical and hydraulic property data that will eventually be included in HEIS. It is likely that a smaller subset of the data that are currently in the SoilVision ${ }^{\circledR}$ database will be transferred to HEIS and made available via the Virtual Library, and this database will be expanded over time as more high-quality, well-documented, and traceable data are generated on other projects. 



\subsection{References}

Freeman EJ and GV Last. 2003. Vadose Zone Hydraulic Property Letter Report. WMP-17524, Rev. 0, Fluor Hanford, Richland, Washington.

Guber AK, YA Pachepsky, MTh Van Genuchten, WJ Rawls, J Simunek, D Jacques, TJ Nicholson, and RE Cady. 2006. "Field-Scale Water Flow Simulations Using Ensembles of Pedotransfer Functions for Soil Water Retention.” Vadose Zone J 5:234-247.

Oostrom M, ML Rockhold, PD Thorne, GV Last, and MJ Truex. 2006. Carbon Tetrachloride Flow and Transport in the Subsurface of the 216-Z-9 Trench at the Hanford Site: Heterogeneous Model Development and Soil Vapor Extraction Modeling. PNNL-15914, Pacific Northwest National Laboratory, Richland, Washington

Schalla R, RW Wallace, RL Aaberg, SP Airhart, DJ Bates, JVM Carlile, CS Cline, DI Dennison, MD Freshley, PR Heller, EJ Jensen, KB Olsen, RG Parkhurst, JT Rieger, and EJ Westergard. 1988. Interim Characterization Report for the 300 Area Process Trenches. PNL-6716, Pacific Northwest Laboratory, Richland, Washington.

Ward AL, ME Conrad, WD Daily, JB Fink, VL Freedman, GW Gee, GM Hoverston, MJ Keller, EL Majer, CJ Murray, MD White, SB Yabusaki, and ZF Zhang. 2006. Vadose Zone Transport Field Study Summary Report. PNNL-15443, Pacific Northwest National Laboratory, Richland, Washington.

Williams MD, ML Rockhold, PD Thorne, and Y Chen. 2008. Three-Dimensional Groundwater Models of the 300 Area at the Hanford Site, Washington State. PNNL-17708. Pacific Northwest National Laboratory, Richland, Washington 



\section{Distribution}

No. of

Copies
No. of

Copies

2 Local Distribution

Pacific Northwest National Laboratory

G.V. Last

M.L. Rockhold

K6-81

K9-36 


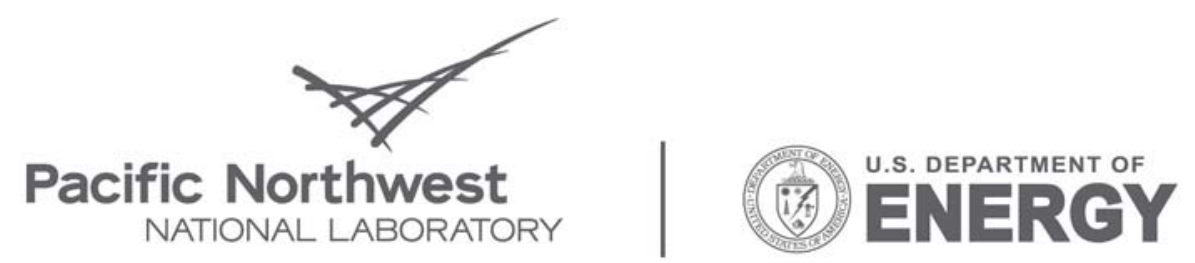

Proudly Operated by Battelle Since 1965

902 Battelle Boulevard

P.O. Box 999

Richland, WA 99352

1-888-375-PNNL (7665)

www.pnl.gov 